\title{
An Introduction to Student Quality Circle at College of Business Administration, Salman bin Abdulaziz University, Al Kharj, Kingdom of Saudi Arabia-An Empirical Study
}

\author{
Mohammad Rishad Faridi ${ }^{1}$, Nasser Saad Al Kahtani ${ }^{1}$, Teg Alam ${ }^{1}$ \& Said Malki ${ }^{2}$ \\ ${ }^{1}$ College of Business Administration, Salman bin Abdulaziz University, Al Kharj, Kingdom of Saudi Arabia \\ ${ }^{2}$ Strategic Planning Consultant, Salman bin Abdulaziz University, Al Kharj, Kingdom of Saudi Arabia \\ Correspondence: Mohammad Rishad Faridi, Department of Marketing, College of Business Administration, PO \\ Box 165, Salman bin Abdulaziz University, Al Kharj 11942, Kingdom of Saudi Arabia. Tel: 966-541-879-473. \\ E-mail: m.faridi@sau.edu.sa
}

Received: June 15, 2014 Accepted: July 28, 2014 Online Published: August 21, 2014

doi:10.5539/ies.v7n9p148

URL: http://dx.doi.org/10.5539/ies.v7n9p148

\begin{abstract}
Catch'em young for imparting hands-on rigorous academic training. This is what has been relentlessly pursued while dealing with the undergraduate students of business management who are to be thoroughly exposed to the whole gamut of quality work life. Whether they opt for corporate career or pursue masters or choose be an entrepreneur, their exposure to the dynamics of quality management must be ensured most likely at student level. Needless to say that the student is more adaptive to change of attitude, behavior, learning etc., and is prone to imbibing the changes without any resistance. One of the collaborative approaches gaining popularity globally is the Student Quality Circle (SQC), an initiative for raising the bar of quality learning and quality teaching. To the best of our knowledge, Quality Circle very much in the vogue, does exist at scores of manufacturing units in Kingdom of Saudi Arabia but this has not yet taken roots in the academic field. This research is essentially a pilot study done at College of Business Administration, Salman bin Abdul-Aziz University, Al-Kharj. The concept "student's quality circle" has been proved quite effective to a larger extent and its encouraging findings will prompt other colleges to opt for it. The study has done an objective analysis of pre and post session implementation of student quality circle and it has carefully measured its empirical impact on student' $s$ traits, attitude, learning, extracurricular activities, individual versus team chemistry, leadership, incubation of quality mind set, total quality environment, and student faculty relationship etc.
\end{abstract}

Keywords: student quality circle, collaboration, teaching \& learning, intended learning outcome

\section{Introduction}

Notwithstanding its phenomenal success, Students quality circle is still an underestimated concept in the contemporary world of education. This concept got originated in the east but its rapid and careful implementation in education sector paid rich dividends in the west. The enormous inherent power of SQC has literally redefined education management, methodology, power of transforming students' lives from reactive personality to being proactive, from being good to smart etc. SQC is based on a firm coordinated approach which moves on a next horizon that is cooperative level that finally stitches up strong and sound ties. It gives shape to collaborative teaching and learning methodology. However this concept of working together in solving issues cannot become functional if it is used as a tool of nit-picking and is dominated by some specific members or groups backed by the power.

\subsection{History of Quality Circle}

As per Wikipedia "Quality Circles were first established in Japan in 1962. Credit goes to Kaoru Ishikawa". It is a mechanism to solve issues pertaining to workplace especially of the workers. The main objective is to resolve issues instantly which ultimately helps in reduction of unproductive work, wastage, errors, and enhances communication skills etc. thus ensures over all well-being of the company. With the introduction of quality circle, the whole environment gets change for the better, productivity gets increased and all feel motivated to work together. 
Quality circle journey started from Nippon Wireless and Telegraph Company but it gradually spreads over 35 organizations in the very first year. In several countries such as China, there are more than 20 million active quality circles. It is important to note that in education sector the first quality circle was formed in India called as Student Quality Circle (SQC) and soon it gained currency across the globe.

\subsection{History of Students Quality Circle}

As per Wikipedia "Student Quality Circles work on the original philosophy of Management" The very first student quality circle was formed in Lucknow, a city in North India. Slowly and steadily, it got momentum and people came to know about its benefits. Many educational institutions within India and outside have put it into practice.

Wikipedia informs "The World Council for Total Quality \& Excellence in Education was established in 1999 with its Corporate Office in Lucknow and head office at Singapore". In Nepal, Prof. Dinesh P. Chapagain has done a remarkable work in SQC. He has coined a term "QUEST" for this initiative and written a book titled "A Guide Book on Students' Quality Circle: An Approach to prepare Total Quality People" This book has become a tear away success as it spelt out the concept and its implementation strategy with remarkable ease. The book sets off standard guidelines from inspection, formulation to finally implementation of SQC.

Circle symbolizes equality (all students are 100\% equal which continuously moves, with no fixed start and finish but mutual respect, trust, and a strong will for working together all come into play. Group learning is encouraged as group tends to have common interest and goals. These voluntary- driven circles are authentic, natural and original.

\subsection{Brief of Students Quality Circle}

Circle revolves around connecting, transforming, learning and understanding. Each student has an equal view and opinion and moves in a circular fashion and not in a vertical way which tends to be bureaucratic, power driven and authoritative. It's horizontal approach tends to be linear and flat. The main purpose is to sit and discuss day to day stumbling blocks threadbare, and have brain storming sessions for resolving them. Now hindrances and weaknesses are transformed into the opportunities and students nurture an urge to overcome the weaknesses and make it as an opportunity.

The role of the facilitator is to play down the ego and encourage students to be honest for discussing their weaknesses. Students at university tend to be innocent and humble as compared to adults working at other places.

Problem solving technique approach is put to use with a view to transforming problems to solutions, thus student's perception about a problem gets totally changed (Solving to a solution) now problem facilitates solution and it no longer remains a stumbling block. Facilitators adopt a "Low-hanging fruit" strategy to spark a flame of wisdom to boost the morale of the student from the very beginning. SQC encourages petty problem solving from the backdrop of larger perspective by ensuring every individual participation and support. Big problems are broken into small pieces so that the small issues can be handled at ease. Post- problem solving solutions trigger off an ambience of celebration. This whole process is intended to make the students stronger and empowered. Problem solving is done by employing an organized and systematic approach. Tools like 5 why's, Root cause analysis, Cause and effect method are roped in. Approach to narrowing down than seeing the big picture is the essence of SQC.

Problem solving is always placed in a deeper perspective rather than a surface perspective. Students are encouraged to be novel and creative in problem solving exercises. Infusing a trust and faith in overcoming hindrances and weaknesses with a recognition by "pat a back" concept is what that keeps students going.

Problem solving is an interactive and interesting process where students mutually help each other in solving issues by sacrificing and helping other colleagues, this gesture unfailingly develops a mutual respect in many ways such as spirit of team work, listening, initiative, transparency in decision making, awareness, effective communication and improving the soft skills etc. Quality circle culture is truly beneficial to the students if they regularly practice it. They inspire from each other and they should say "Let work together in solving issues and celebrate success"

Though there are numerous Quality Circles operating in Kingdom of Saudi Arabia, one hardly comes across with a Student Quality Circle running at any college or university in Kingdom of Saudi Arabia. Our College of Business Administration, Al-Kharj under Salman bin Abdul-Aziz University, Al-Kharj truly feels proud of having put this highly significant and innovative initiative into action. Our college will be shortly going for the NCAAA accreditation so it is absolutely essential to involve students in this never-ending journey of quality 
improvement initiative.

\section{Literature Review}

Student Quality Circle comprises a group of students that form a "committee" (voluntary) with the objective of having quality in teaching and learning by meeting each other and also ensures the presence of the instructor regularly (Once in 15 days or once in a month). With mutual collaborative approach, frank discussions are encouraged, consequently problems are resolved, expectations of students and faculty are matched and it also paves the way for cordial learning environment.

Once the student completes the undergraduate program, the expectations of employer especially in corporate field are enhanced so that they can get the highest level of productivity from day one. On the contrary, the newly graduate student seems eager to get a feel about the corporate working environment. However this mismatch of expectations and reality gap can be narrowed by equipping this young student with necessary resources to face challenges and become competitive.

This has engendered a need for inculcating quality work life, honing personality traits, gaining knowledge/skills, building up confidence and be able to identify, analyze, solve and finally able to become self-independent. This may sound pedantic and bookish but a careful implementation fully transforms the student university. Ennals et al. (2010). In Student Quality Circle students are the leaders whereas teachers support and facilitate the whole process, challenging the "traditional power structures through collaboration". Collaborative approach and sharing of knowledge vertically as well as horizontally transform the educational institution to a learning organization. From the perspective, students are always instructed to work hard, get good marks, learn the maximum, and excel with distinction in examination, but on the other hand the pedagogy of faculty is stereo typed, thus there is a wide gap between expectation of faculty and the satisfaction level of students, this can be minimized by SQC which makes use of collaborative approach.

According to Nahai et al. (2011) it creates a student-centric environment where students are involved and encouraged to participate enthusiastically in their learning environment. Voice of students is not just heard but action plan is prepared to solve issues, this gesture of two way communication and co-operation unleashes the potential and empowers students to be problem solvers. Student's involvement, engagement and empowerment explore a possible all round retention and performance. SQC acts like a catalyst in transforming a passive student environment to an active equal participative environment in shaping a strong academic experience.

Administrators expect students to be motivated, enthusiastic, initiative driven, and active learner but on the contrary students tend to be learners at their own pace owing to pressure of studies and exams. Here SQC helps all stakeholders-students, administrators and faculty members. Nahai et al. (2011) opines that a humble, simple, quick, approach of forming SQC by working with motivated students, can improve total education "through a bottom-up approach". Success of this noble initiative of the students spills over the benefits to the respective faculties teaching the course and program.

Complaints of stakeholders especially society's attitude towards university that they encourage good/high performing students to excel in life whereas average and below average students get demoralized because of the lack of attention in improving their performance. SQC is a vital tool in pulling weak students up, engaging them to identify the weakness, solving problems and overcoming difficulties thus making change happen.

Nahai et al. (2012) says SQCs have been very effective tools in bridging three important parameters: "Quality improvement, Student engagement and the Student learning experience" Student development program formation from top to bottom can be very authentic once it comes from the student's side. Engaging and working in team spurs innovation and creativity. SQC model can be very well emulated at a higher level or different scenario. Involvement and the essence of problem solving by participation is a much authentic approach of helping each other "a catalyst for larger change in the economy and society".

\section{Research Objective}

The following are the research objectives:

1) To make analysis and its impact on introduction of Students Quality Circle at College of Business Administration.

2) To find the effectiveness of Students Quality Circle by concentrating on perception, expectation and satisfaction level.

3) To make strategies in being successful in student intended learning outcome.

4) To make analysis and identify how various variables help, support and contribute in producing a congenial 
learning environment.

5) To analyze relationship building between faculty, administrator and students.

6) To analyze the impact on shareholders in implementing student's quality circle.

7) Find, how to build and improve student resource development?

8) How does student quality circle help in classroom management?

\subsection{Research Significance}

College of Business Administration, Al-Kharj under Salman bin Abdul-Aziz University, Al-Kharj is under the process of accreditation by the National Commission for Academic Accreditation and Assessment. In the National Qualifications Framework for higher education, impetus is given to develop students with interpersonal skills and making them to be perfect team players. The attitude orientation is be open for a change, ideas etc. so there is more reason to introduce quality tool called Students Quality Circle which is in the alignment with NCAAA student intended learning outcome.

As per NCAAA (2010) to grow and develop interpersonal and communication skills, a blend of habits, knowledge and attitudes are very vital. These virtues are not just important in a student's life but are required more during post student life, a matter of fact for lifelong. A continuous improvement of skills with special emphasis on "group participation, leadership and personal and social responsibility, including ethical behavior values and urge to involve in self-initiated learning strategies will normally require involvement, participation in appropriate group activities" (Student Quality Circle). In academia rules and regulations are important guidelines but most important are the soft skills like attitude change, a powerful tool which affects the "views and actions".

With this pilot initiative and once proved successful which we are very sure of SQC would be implemented in other departments of College of Business Administration Al-Kharj and other affiliated colleges of various disciplines and henceforth this quality wave will spread beyond boundaries.

\section{Methods}

Students under Students Quality Circle are as follows in the semester September 2013 to January 2014:

University: Salman bin Abdul-Aziz University, Al-Kharj, Kingdom of Saudi Arabia

College: Business Administration, Al-Kharj

Department: Management

Program: Bachelor of Science in Business Administration

Course: Strategic Management Using Computer Simulation

Group-929 and Group-1175

Questionnaire filled by students before implementing quality circle and subsequently questionnaire filled after completing this course. A gap analysis is done to identify the impact of SQC in the learning \& teaching environment in the department, class room etc. In this study, gap analysis tool was used by comparing the post-average of variables with the pre-average of variables.

\section{Results}

5.1 Demographic Profile of Students of Strategic Management Using Computer Simulation (Group-929)

Table 1. Demographic profile of students of strategic management using computer simulation (Group-929)

\begin{tabular}{lllll}
\hline S. No & \multicolumn{1}{l}{ Demographics } & Frequency & Percentage \\
\hline \multirow{4}{*}{1} & & $\leq 20$ years & 1 & 14.3 \\
& Age & 20-25 years & 5 & 71.4 \\
& & 25-30 years & 1 & 14.3 \\
\multirow{2}{*}{2} & & $\geq 30$ years & 0 & 00.0 \\
& \multirow{3}{*}{3} & Semester & 7 & 100 \\
& & 2 & 0 & 0.00 \\
& \multirow{2}{*}{ Place } & Urban & 7 & 100 \\
& & Rural & 0 & 00.0 \\
\hline
\end{tabular}


Table 2. Gap analysis of students of the course strategic management using computer simulation (Group-929) towards the following variables

\begin{tabular}{llll}
\hline \multirow{2}{*}{ Variable } & \multicolumn{2}{l}{ Pre Observation } & \multicolumn{2}{l}{ Post Observation } & \multirow{2}{*}{ Gap=(II)-(I) } \\
\cline { 2 - 3 } & Mean(I) & Mean(II) & 0.00 \\
\hline Positive Attitude. & 4.00 & 4.00 & 0.00 \\
High Motivation. & 3.86 & 3.86 & -0.43 \\
Positive learning outcome. & 4.57 & 4.14 & 0.00 \\
Personality Development. & 4.00 & 4.00 & 0.71 \\
Very Enthusiastic and have new ideas. & 3.43 & 4.14 & 0.00 \\
Strong resources. & 3.71 & 3.71 & 0.43 \\
Very Creative. & 3.43 & 3.86 & 0.71 \\
Desire to learn. & 3.86 & 4.57 & 0.00 \\
Adaptive to conditions. & 3.86 & 3.86 & 0.43 \\
Good in Solving problems. & 3.29 & 3.71 & 1.29 \\
Satisfied with extracurricular activities. & 2.71 & 4.00 & 0.14 \\
Team player. & 3.57 & 3.71 & 0.00 \\
Strong Decision Making Skills. & 4.14 & 4.14 & 0.00 \\
Having leadership qualities. & 4.29 & 4.29 & 0.14 \\
Having Confidence. & 4.14 & 4.29 & -0.14 \\
Sense of self-worthiness. & 4.14 & 4.00 & 0.29 \\
Congenial learning atmosphere. & 3.43 & 3.71 & 0.14 \\
Satisfied with content of curriculum. & 3.00 & 3.14 & -0.43 \\
Having Critical Thinking Skills. & 3.71 & 3.29 & 0.06 \\
Overall Satisfied. & 3.14 & 3.20 & \\
\hline
\end{tabular}

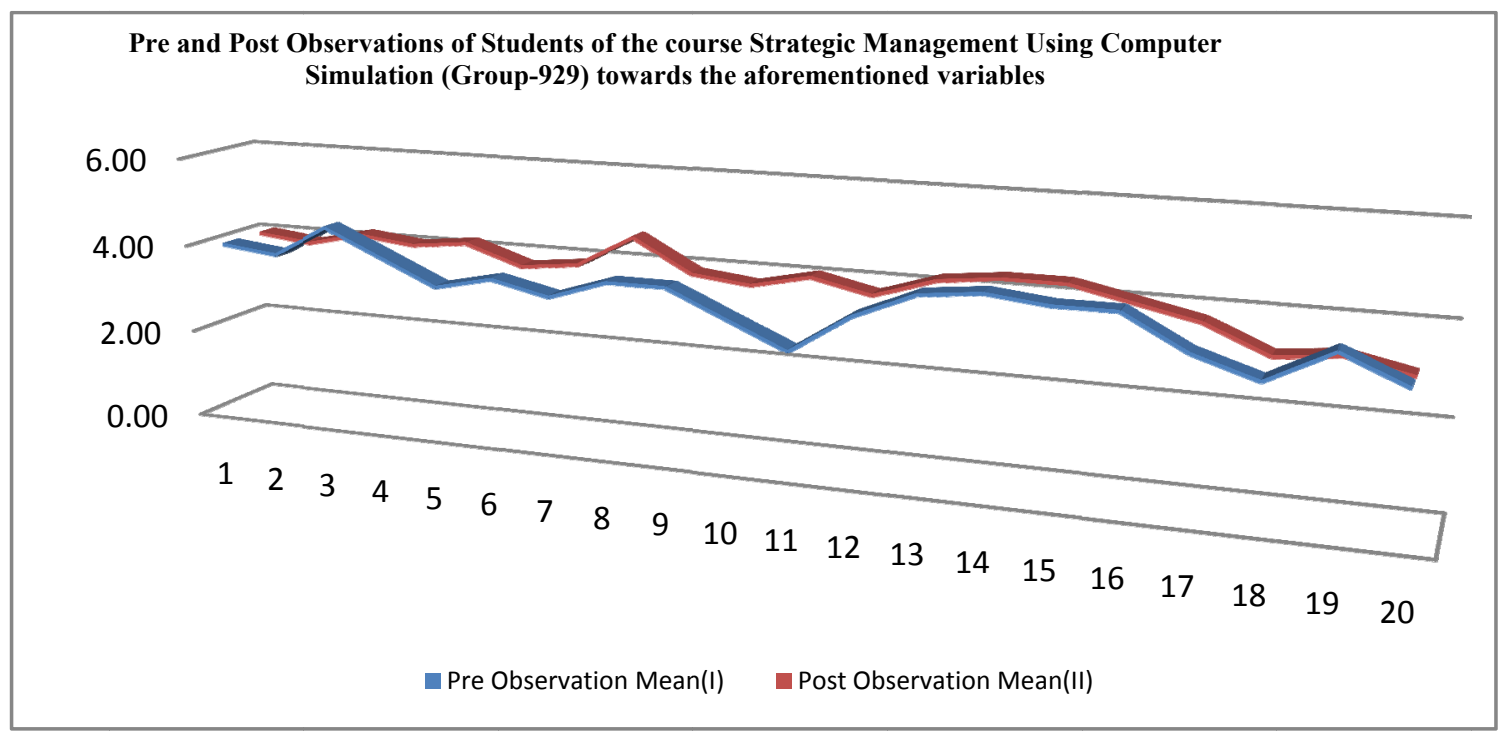

Figure 1. Graphical presentation of pre and post observations of students of the course strategic management using computer simulation (Group-929) towards the aforementioned variables 
Introduction of Student quality circle is a humble beginning of creating quality consensus at a grass root level (Student level) Voice of students is quite encouraging wherein students started feeling that they are involved in class room and day to day affairs of the college. Students felt at ease when a friendly, informal environment was created.

Table 3. Gap analysis of students of the course strategic management using computer simulation (Group-929) towards the following perceived variables

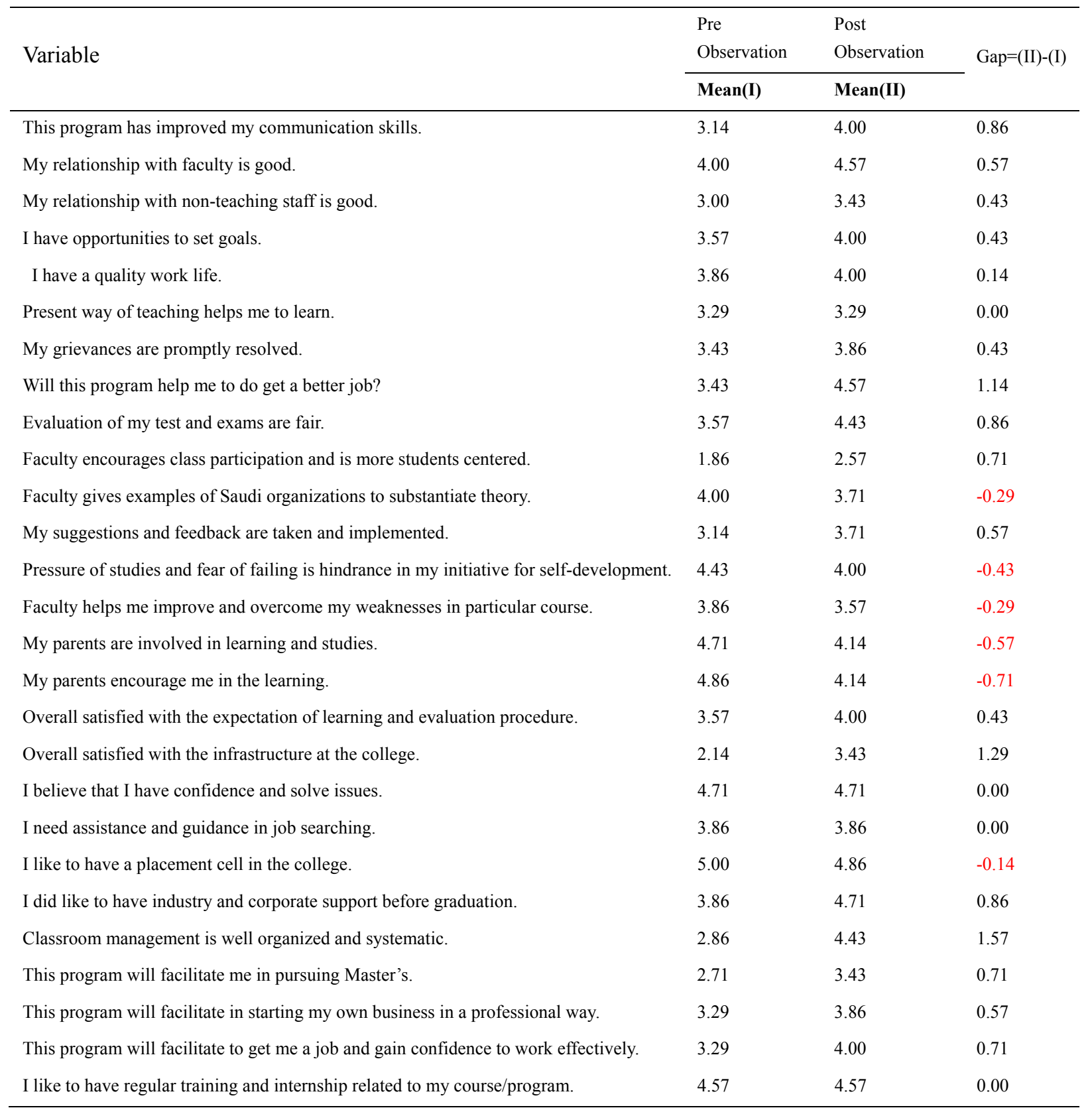




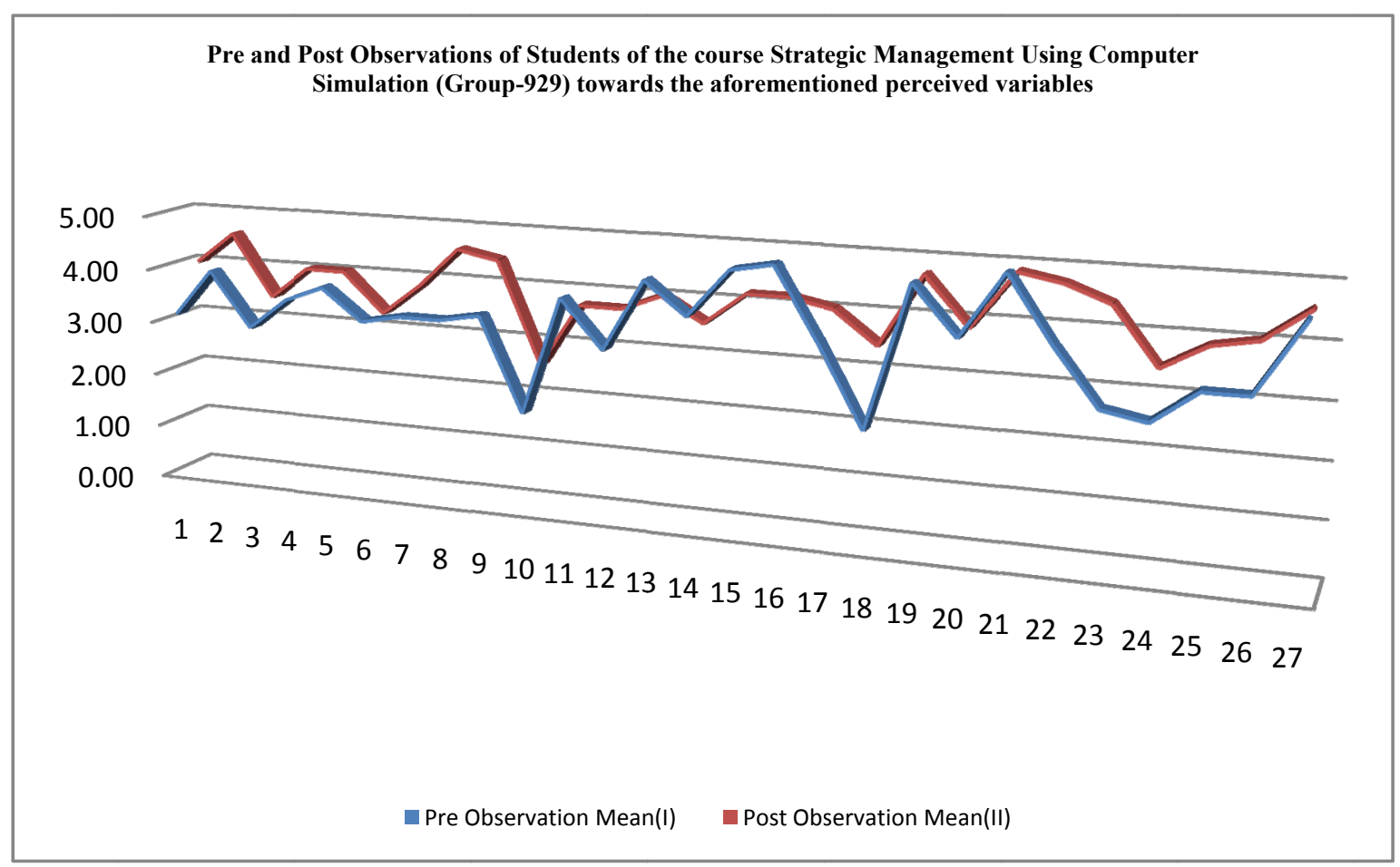

Figure 2. Graphical presentation of pre and post observations of students of the course strategic management using computer simulation (Group-929) towards the aforementioned perceived variables

Relationship after class hours with the facilitator has been improved. Students were involved and engaged in the problem solving exercise. It is very significant to find that some students volunteered in helping weaker students in completing assignments and group mini project.

\subsection{Demographic Profile of Students of Strategic Management Using Computer Simulation (Group-1175)}

Table 4. Demographic profile of students of strategic management using computer simulation (Group-1175)

\begin{tabular}{lllll}
\hline S. No & \multicolumn{2}{l}{ Demographics } & Frequency & Percentage \\
\hline \multirow{4}{*}{1} & & $\leq 20$ years & 0 & 00.0 \\
& Age & 20-25 years & 6 & 85.7 \\
& & 25-30 years & 1 & 14.3 \\
& & $\geq 30$ years & 0 & 00.0 \\
2 & Semester & 1 & 6 & 85.7 \\
& & 2 & 1 & 14.3 \\
3 & \multirow{3}{*}{ Place } & Urban & 7 & 100 \\
& & Rural & 0 & 00.0 \\
\hline
\end{tabular}


Table 5. Gap analysis of students of the course strategic management using computer simulation (Group-1175) towards the following variables

\begin{tabular}{llll}
\hline \multirow{2}{*}{ Variable } & \multicolumn{2}{l}{ Pre Observation } & \multicolumn{2}{l}{ Post Observation } & \multirow{2}{*}{ Gap=(II)-(I) } \\
\cline { 2 - 3 } & Mean(I) & Mean(II) & 0.57 \\
\hline Positive Attitude. & 4.00 & 4.57 & 0.43 \\
High Motivation. & 3.86 & 4.29 & -0.43 \\
Positive learning outcome. & 4.57 & 4.14 & 0.43 \\
Personality Development. & 4.00 & 4.43 & 0.71 \\
Very Enthusiastic and have new ideas. & 3.43 & 4.14 & 0.00 \\
Strong resources. & 3.71 & 3.71 & 0.43 \\
Very Creative. & 3.43 & 3.86 & 0.71 \\
Desire to learn. & 3.86 & 4.57 & 0.00 \\
Adaptive to conditions. & 3.86 & 3.86 & 0.43 \\
Good in Solving problems. & 3.29 & 3.71 & 1.29 \\
Satisfied with extracurricular activities. & 2.71 & 4.00 & 0.14 \\
Team player. & 3.57 & 3.71 & 0.00 \\
Strong Decision Making Skills. & 4.14 & 4.14 & 0.00 \\
Having leadership qualities. & 4.29 & 4.29 & 0.14 \\
Having Confidence. & 4.14 & 4.29 & 0.14 \\
Sense of self-worthiness. & 4.14 & 4.29 & 0.29 \\
Congenial learning atmosphere. & 3.43 & 3.71 & 0.14 \\
Satisfied with content of curriculum. & 3.00 & 3.14 & 0.00 \\
Having Critical Thinking Skills. & 3.71 & 3.71 & 0.29 \\
Overall Satisfied. & 3.14 & 3.43 & \\
\hline
\end{tabular}

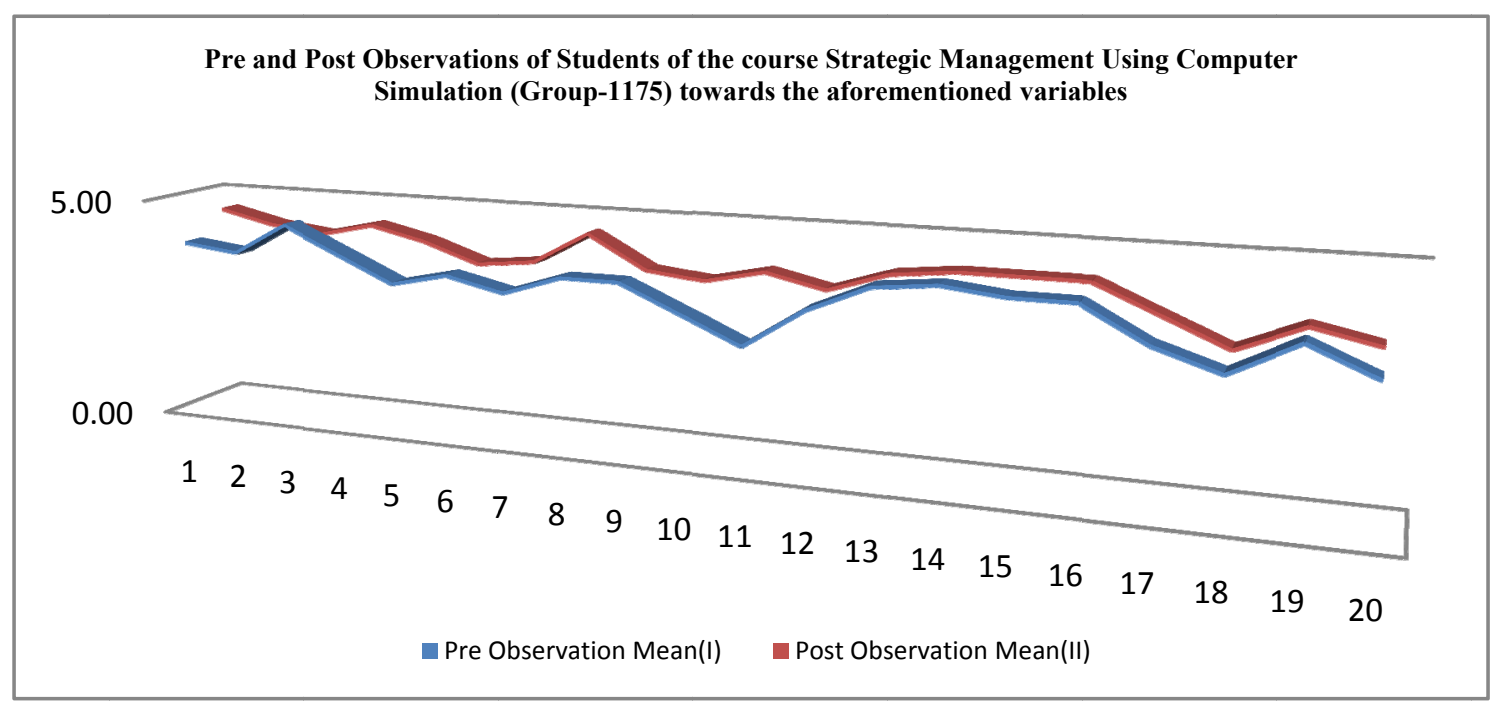

Figure 3. Graphical presentation of pre and post observations of students of the course strategic management using computer simulation (Group-1175) towards the aforementioned variables 
Voice of students was skewing towards change in their thinking process, attitude and improving their relationship among classmates as well as with the facilitators. Shift of the environment from formal stereo type of interaction to a friendlier, informal environment made students feel at ease.

Table 6. Gap analysis of students of the course strategic management using computer simulation (Group-1175) towards the following perceived variables

\begin{tabular}{|c|c|c|c|}
\hline \multirow[t]{2}{*}{ Variable } & \multirow{2}{*}{$\begin{array}{l}\text { Pre Observation } \\
\text { Mean(I) }\end{array}$} & $\begin{array}{l}\text { Post } \\
\text { Observation }\end{array}$ & \multirow{2}{*}{$\begin{array}{l}\text { Gap }= \\
\text { (II)-(I) }\end{array}$} \\
\hline & & Mean(II) & \\
\hline This program has improved my communication skills. & 3.14 & 4.00 & 0.86 \\
\hline My relationship with faculty is good. & 4.00 & 4.57 & 0.57 \\
\hline My relationship with non-teaching staff is good. & 3.00 & 3.43 & 0.43 \\
\hline I have opportunities to set goals. & 3.57 & 4.00 & 0.43 \\
\hline I have a quality work life. & 3.86 & 4.00 & 0.14 \\
\hline Present way of teaching helps me to learn. & 3.29 & 3.29 & 0.00 \\
\hline My grievances are promptly resolved. & 3.43 & 3.86 & 0.43 \\
\hline Will this program help me to do get a better job? & 3.43 & 4.57 & 1.14 \\
\hline Evaluation of my test and exams are fair. & 3.57 & 4.43 & 0.86 \\
\hline Faculty encourages class participation and is more students centered. & 1.86 & 2.57 & 0.71 \\
\hline Faculty gives examples of Saudi organizations to substantiate theory. & 4.00 & 3.71 & -0.29 \\
\hline My suggestions and feedback are taken and implemented. & 3.14 & 3.71 & 0.57 \\
\hline $\begin{array}{l}\text { Pressure of studies and fear of failing is hindrance in my initiative for } \\
\text { self-development. }\end{array}$ & 4.43 & 4.43 & 0.00 \\
\hline $\begin{array}{l}\text { Faculty helps me improve and overcome my weaknesses in particular } \\
\text { course. }\end{array}$ & 3.86 & 4.00 & 0.14 \\
\hline My parents are involved in learning and studies. & 4.71 & 4.57 & -0.14 \\
\hline My parents encourage me in the learning. & 4.86 & 4.57 & -0.29 \\
\hline $\begin{array}{l}\text { Overall satisfied with the expectation of learning and evaluation } \\
\text { procedure. }\end{array}$ & 3.57 & 4.43 & 0.86 \\
\hline Overall satisfied with the infrastructure at the college. & 2.14 & 3.43 & 1.29 \\
\hline I believe that I have confidence and solve issues. & 4.71 & 4.71 & 0.00 \\
\hline I need assistance and guidance in job searching. & 3.86 & 3.86 & 0.00 \\
\hline I like to have a placement cell in the college. & 5.00 & 4.86 & -0.14 \\
\hline I did like to have industry and corporate support before graduation. & 3.86 & 4.71 & 0.86 \\
\hline Classroom management is well organized and systematic. & 2.86 & 4.43 & 1.57 \\
\hline This program will facilitate me in pursuing Master's. & 2.71 & 3.43 & 0.71 \\
\hline $\begin{array}{l}\text { This program will facilitate in starting my own business in a } \\
\text { professional way. }\end{array}$ & 3.29 & 3.86 & 0.57 \\
\hline $\begin{array}{l}\text { This program will facilitate to get me a job and gain confidence to work } \\
\text { effectively. }\end{array}$ & 3.29 & 4.00 & 0.71 \\
\hline $\begin{array}{l}\text { I like to have regular training and internship related to my } \\
\text { course/program. }\end{array}$ & 4.57 & 4.57 & 0.00 \\
\hline
\end{tabular}




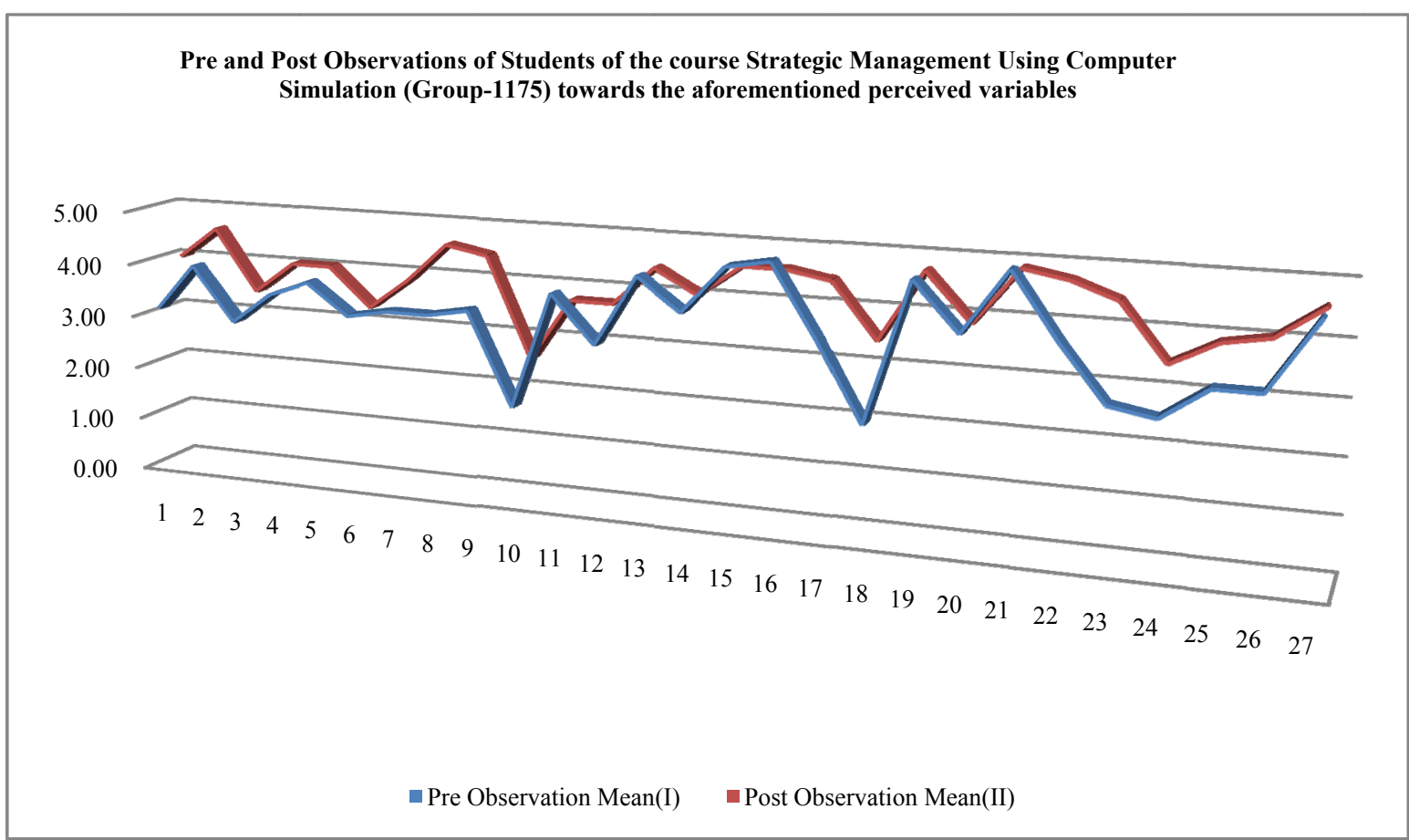

Figure 4. Graphical presentation of pre and post observations of students of the course strategic management using computer simulation (Group-1175) towards the aforementioned perceived variables

Students recognized SQC as a tool or a platform to resolve grievances with the facilitator. The best part was it was a circular process and had a cascading effect in terms of grievances list students had in their pocket. The overall impact of SQC improved the learning and teaching environment.

\subsection{A Heuristic Model of Student Quality Circle}

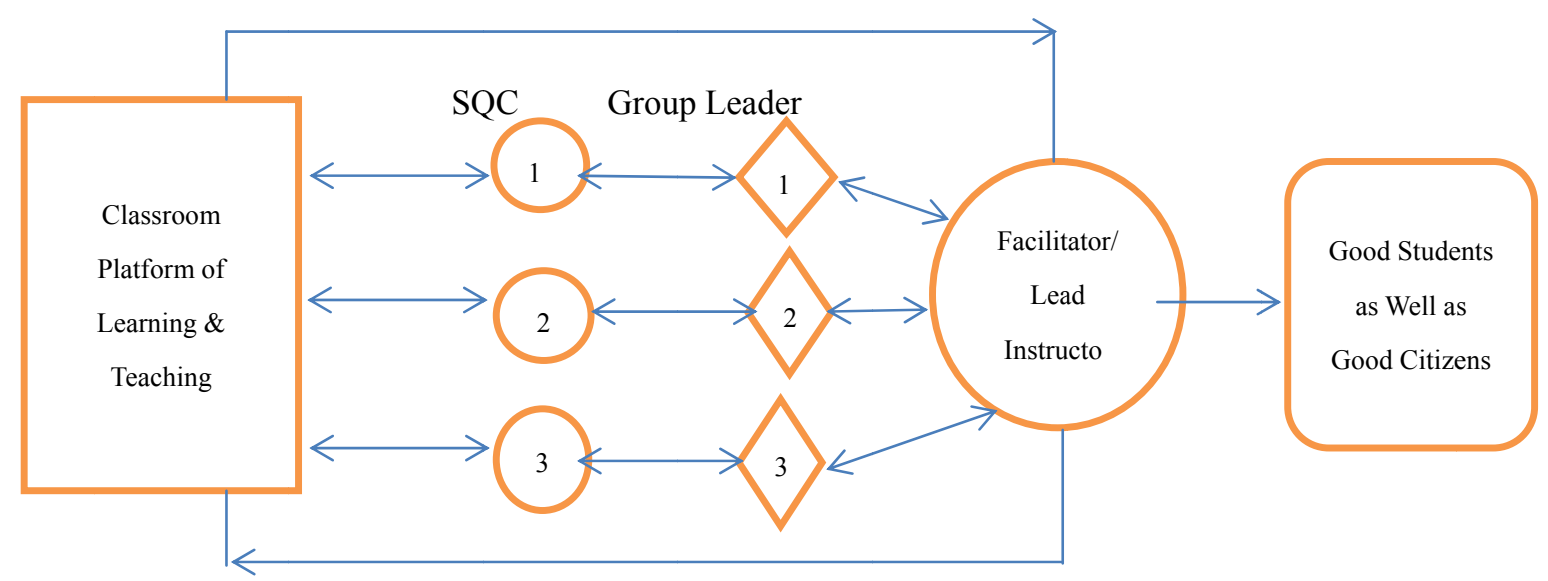

Figure 5. Heuristic model of student quality circle

Student Quality Circle if done in a well-planned way can be an inspiring tool for student's engagement. Students if oriented in the beginning of the semester on the first day in the class with a detailed briefing about the approach SQC will surely yield enormous benefits by improving teaching and learning through congenial relationship between faculty and students. This model is an outcome of the introduction of Student Quality Circle in the Department of Management at College of Business Administration, Salman bin Abdul-Aziz University, Al Kharj, KSA. The process is viewed as a heuristic approach which impacts a positive learning and teaching environment being SQC directly interfacing with the faculty and students. 
Classroom is presumably a shrine of learning and SQC stimulates simple classroom by possible shuffling and changes in order to improve. The continuous improvement is possible when classroom is intercepted by a process of betterment or else the basic role of classroom will be perpetual without any introspection.

SQC breaks the traditional shackles of silo learning to a faculty empowering students and each SQC consists of a group leader. The transformation of mere passive students to active and then in due course of time being group leaders transforms their personality from a cat to a lion (all in the cat family)

Output has to be a student with the spark of potential power. SQC acts like a pole vault in leaping students to a next level of life enhancement. Feedback, communication, co-ordination moves continuously and it becomes a continuous process of thinking, rethinking and creating value for all.

\section{Discussion}

SQC is a great initiative especially for our university which is new and more important culture of quality at grass level can be infused especially among students. Quality Circle creates openness, strengthens self-problem solving skills attitude, and creates respect to all.

- SQC should be initiated at semester level 1 and should continue till the 8 th level (last/final) in order to have a continuity of this good practice so that it gets engraved in the student's life.

- SQC is an effective tool in promoting differentiated learning techniques in the classroom by forming flexible grouping, homogenisation of bright, average and weaker students (evenly spread). Facilitator should use purposive sampling technique to create SQC members.

- SQC creates an environment of student centric, fairness, student empowerment, improving solving skills thus increasing employability skills of the respective students

- Students who like to pursue entrepreneurship will experience hands on insight about the power of Quality Circle and more important preventive action can be taken proactively to minimise the reason of failures. This quality philosophy they can use in their work place to get benefits.

- $\quad \mathrm{SQC}$ can be a role model for other colleges to replicate.

- Before SQC is introduced, a thorough orientation of the quality circle concept has to be educated in order to make seamless progress.

- Visual boards at specific strategic places should be installed in order to create awareness about the progress and development

- Intended learning outcome can be accomplished by better planning, formulating, assessing and finally evaluating with the help of SQC. As informal discussions between the facilitator and students are encouraged. Especially in business program it improves the employability skills of the students.

\section{Conclusion}

On a heuristic perspective it is indeed an attempt to bring forth faculty and students together in achieving the College and finally University goals. SQC has to be redefined in this highly advanced technology era where concept of e SQC can be introduced to this digital native generation.

But the personal touch should not be diluted which is in fact the strength of SQC. Thus a balance of traditional approach with the blend of ICT will create a holistic dimension to the student, faculty, administrators and quality department. Researchers, educationalist, policy makers can further dive into in unleashing the potential and power of SQC.

\section{Acknowledgements}

This present research is a part of research project funded by Deanship of Scientific Research, Salman bin Abdulaziz University, Al-Kharj, Kingdom of SaudiArabia. Researchers are grateful to the Deanship of Scientific Research, Salman bin Abdulaziz University, Al-Kharj, Kingdom of Saudi Arabia for their financial support in completing this work.

\section{References}

Baligadoo, P. D. (2012). An evaluation of students' quality circles and the world council for total quality and excellence in education. Springer, 27, 337-355.

Chapagain, D. (2006). A guide to Students' Quality Circles. Quest Nepal, Kathmandu.

Chapagain, D. (2006). Guide to students' quality circles: an approach to prepare total quality people. Nepal, Network for Quality, Productivity and Competitiveness.

Cushner, K., \& Brislin, R. W. (1996). Intercultural interactions: A practical guide. Cross cultural research and 
methodology, 9 (2nd ed). London: Sage Publications.

Ennals, R. (2007). Quality for peace. International journal of quality and standards, 1(1). London: British Standards Institutions. Retrieved from http://www.bsieducation.org/Education/downloads/ijqs/paper5.pdf

Ennals, R. (2010). Creating collaborative advantage: Students' quality circles. Keynote talk, Kathmandu.

Ennals, R., \& Salomon, R. (Eds.). (2011). Older workers in a sustainable society. Peter Lang, Frankfurt.

Ennals, R., \& Haga, T. (2010). Missing links for development: Students' quality circles and network orchestration. Presentation.

Ennals. R. (2012). Quality as empowerment: Going around in circles. Springer, 27, 331-335.

Hutchins, D. (2008). Hoshin Kanri: The strategic approach to continuous improvement. Gower, Farnham.

Hutchins, D. C. (1985). The Quality Circles Handbook. New York: Pitman Press.

Hutchins, D. C. (1999). Just In Time. Farnham, Surrey: Gower Publishing.

Hutchins, D. C. (2008). HoshinKanri: The strategic approach to continuous improvement. Burlington, Vermont: Gower.

Ishikawa, K. (1970). Quality control circles. Japanese Union of Scientists and Engineers, Tokyo.

Ishikawa, K. (1986). QC guide to quality control. Asian Productivity Association, Tokyo.

Juran, J. M. (1992). Juran on quality by design: The new steps for planning quality into goods and services. New York: Free Press.

Montana, P. J., \& Bruce, H. C. (2008). Management (4th ed.). Barron's.

Nahai, R., \& Osterberg, S. (2012). Higher education in a state of crisis: A perspective from students' quality circle. Springer, 27, 387-398.

NCAAA. (2010). Accreditation Documents. Retrieved January 10, 2014, from http://ncaaa.org.sa/english/adefault.aspx

Quality Circle. (2014). In Wikipedia, the free encyclopedia. Retrieved January 4, 2014, from http://en.wikipedia.org/wiki/Quality_circle

Salam, A. (2012). Students quality circles-A co-curricular activity to empower youth. Retrieved December 10, 2013, from http://pakobserver.net/201210/27/detailnews.asp?id=179945

Schmidt, S. J., Parmer, M. S., \& Bohn, D. M. (2005). Using quality circles to enhance students involvement and course quality in a large undergraduate food science and human nutrition course. Journal of Food Science Education, 1 .

Tang, T. L. P., Tollison, P. S., \& Whiteside, H. D. (1993). Differences between active and inactive quality circles in attendance and performance. Public Personnel Management, 22, 579-590.

Tang, T. L. P., Tollison, P. S., \& Whiteside, H. D. (1987). The effect of quality circle initiation on motivation to attend quality circle meetings and on task performance. Personnel Psychology, 40, 799-814. http://dx.doi.org/10.1111/j.1744-6570.1987.tb00625.x

Tang, T. L. P., Tollison, P. S., \& Whiteside, H. D. (1989). Quality circle productivity as related to upper-management attendance, circle initiation, and collar color. Journal of Management, 15, 101-113. http://dx.doi.org/10.1177/014920638901500109

Tang, T. L. P., Tollison, P. S., \& Whiteside, H. D. (1991). Manager's attendance and the effectiveness of small groups: The case of quality circles. Journal of Social Psychology, 131(3), 335-344. http://dx.doi.org/10.1080/00224545.1991.9713860

Tang, T. L. P., Tollison, P. S., \& Whiteside, H. D. (1996). The case of active and inactive quality circles. Journal of Social Psychology, 136, 57-67. http://dx.doi.org/10.1080/00224545.1996.9923029

Totterdill, P., Ennals, R., \& Exton, R. (2012). Workplace innovation: The challenge for public policy. Gower, Farnham13-Terra Stern, Change Management-Adopting a Continuous Improvement Program. 


\section{Copyrights}

Copyright for this article is retained by the author(s), with first publication rights granted to the journal.

This is an open-access article distributed under the terms and conditions of the Creative Commons Attribution license (http://creativecommons.org/licenses/by/3.0/). 